\title{
Increased airway mucins after cardiopulmonary bypass associated with postoperative respiratory complications in children
}

\author{
Hajime Imura, $M D^{\mathrm{a}}$ \\ Heather P. Duncan, MBChB ${ }^{\text {b }}$ \\ Anthony P. Corfield, $\mathrm{PhD}^{\mathrm{c}}$ \\ Neil Myerscough, $\mathrm{MSc}^{\mathrm{c}}$ \\ Massimo Caputo, MDa \\ Gianni D. Angelini, FRCS ${ }^{\mathrm{a}}$ \\ Andrew R. Wolf, MD \\ A. John Henderson, $M D^{b}$
}

From the Bristol Heart Institute, ${ }^{\text {a }}$ Institute of Child Health, ${ }^{\text {b }}$ and Department of Clinical Medicine, University of Bristol, ${ }^{\mathrm{c}}$ Bristol, United Kingdom.

H.I. was supported by a grant from the Nippon Medical School. Funding for the laboratory analysis was provided by a grant from the Medical Research Committee of the United Bristol Hospitals National Health Service Trust, Bristol, United Kingdom.

Received for publication April 14, 2003; revisions requested June 13, 2003; revisions received July 31,2003 ; accepted for publication Aug 21, 2003.

Address for reprints: A. John Henderson, MD, Institute of Child Health, Bristol Royal Hospital for Children, Upper Maudlin St, Bristol BS2 8BJ, UK (E-mail: a.j.henderson@bristol.ac.uk).

J Thorac Cardiovasc Surg 2004;127:963-9 $0022-5223 / \$ 30.00$

Copyright $\odot 2004$ by The American Association for Thoracic Surgery

doi:10.1016/j.jtcvs.2003.07.034
Objective: Airway mucins may play an important role in the mechanism of respiratory complications after cardiopulmonary bypass in infants and children. Our aim was to measure airway mucin levels before and after cardiopulmonary bypass and to determine whether changes in mucin levels were associated with the development of respiratory complications.

Methods: Airway glycoprotein and mucins (MUC5AC, MUC5B, and MUC2) in serial small-volume airway lavage samples from 39 young children who underwent cardiac operations with cardiopulmonary bypass were measured by slot-blot assay with specific antimucin peptide antibodies. The relationship between mucin changes and post-cardiopulmonary bypass respiratory complications was investigated. Airway lavage samples were also collected from 11 children before and after operation without cardiopulmonary bypass, and changes in mucin levels were compared with those in subjects who underwent cardiopulmonary bypass. Airway lavage sample DNA was also measured to investigate the relationship between mucin changes and lung injury.

Results: Glycoprotein, MUC5AC, and MUC5B levels were significantly increased after cardiopulmonary bypass $(P<.001)$ whereas MUC2 level was not. Children with respiratory complications showed significantly higher glycoprotein and MUC5AC levels than did children without respiratory complications before and after cardiopulmonary bypass $(P<.05)$. Increase of total mucin (MUC5AC, MUC5B, and MUC2) during cardiopulmonary bypass showed positive correlation with DNA increase during cardiopulmonary bypass $(r=0.73), \mathrm{PaCO}_{2}(r=0.62)$ and alveolar-arterial oxygen difference $(r=0.55)$ immediately after cardiopulmonary bypass. Increase of total mucin was associated with postoperative respiratory complications and their severity. There were no significant changes detected in airway mucin during operations without cardiopulmonary bypass.

Conclusions: Airway mucins were increased during cardiopulmonary bypass, and this increase was associated with markers of lung injury after cardiopulmonary bypass and with the development of postoperative respiratory complications.

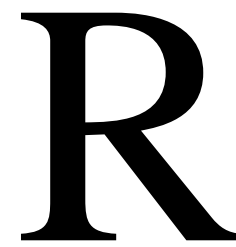

espiratory complications are common in pediatric cardiac surgery, ${ }^{1-2}$ but the mechanisms for such respiratory problems remain poorly understood. Abnormalities include gas exchange failure, hypersecretion, and pulmonary atelectasis, and these are sometimes associated with more serious complications, such as critical hypoxemia, pneumonia, and death.,

Mucins are key components of the mucosal defensive barrier and the host's ability to resist lung injury. The main secreted gel-forming mucins present in the 
TABLE 1. Clinical data of study subjects

\begin{tabular}{|c|c|c|c|}
\hline & No respiratory complication & Respiratory complication & No CPB \\
\hline Subjects (No.) & 25 & 14 & 11 \\
\hline Age (mo, median and interquartile range) & $14.0(2.5-48.0)$ & $12.5(6.0-36.0)$ & $17.0(3.5-68.8)$ \\
\hline Body weight ( $\mathrm{kg}$, median and interquartile range) & $7.4(4.0-15.9)$ & $7.8(4.5-11.5)$ & $10.6(5.8-15.2)$ \\
\hline \multicolumn{4}{|l|}{ Cyanosis (No.) } \\
\hline No & 15 & 6 & 6 \\
\hline Yes & 10 & 8 & 5 \\
\hline \multicolumn{4}{|l|}{ Pulmonary flow (No.) } \\
\hline Increased & 15 & 8 & 4 \\
\hline Normal & 6 & 1 & 2 \\
\hline Decreased & 4 & 5 & 5 \\
\hline \multicolumn{4}{|l|}{ Operations (No.) } \\
\hline Ventricular septal defect repair & 5 & 2 & \\
\hline Atrial septal defect* repair & 4 & 3 & \\
\hline Tetralogy of Fallot repair & 4 & 4 & \\
\hline Arterial switch & 3 & 2 & \\
\hline Valve surgery & 4 & & \\
\hline Patent ductus arteriosus ligation & & & 3 \\
\hline Coactation repair & & & 2 \\
\hline Coactation repair and pulmonary artery banding & & & 1 \\
\hline Blalock-Taussig shunt & & & 5 \\
\hline Others & 5 & 3 & \\
\hline CPB time (min, median and interquartile range) & $52.0(40.1-81.0)$ & $66.5(51.0-109.0)$ & Not applicable \\
\hline Lowest rectal temperature $\left({ }^{\circ} \mathrm{C}\right.$, median and interquartile range) & $28.1(22.1-32.0)$ & $27.7(24.0-28.0)$ & Not available \\
\hline Lowest hemoglobin $(\mathrm{g} / \mathrm{dL}$, median and interquartile range) & $8.1(7.3-9.4)$ & $7.6(6.9-8.2)$ & Not available \\
\hline Ventilation time (h, median and interquartile range) & $11.0(5.0-24.0)$ & $24.0(7.0-80.0)$ & $16.0(1.8-23.6)$ \\
\hline
\end{tabular}

No significant differences were seen between the three groups in each parameter.

* Including partial atrioventricular septal defect.

respiratory tract are MUC5AC, in superficial mucosa, and MUC5B, in the submucosal glands. ${ }^{5-7}$ In normal airways, mucins cover the epithelial surface of the respiratory tract, and mucin production is maintained at a relatively low level. In pathologic conditions such as asthma, bronchitis, and acute respiratory distress syndrome, however, mucin accumulates in the respiratory tract and impairs gas exchange. Bacterial colonization may then lead to infection and lung damage. ${ }^{5-7}$ The study of mucins has relied largely on measurement of gene expression by messenger RNA, giving an indirect assessment of the translated gene product. However, the development of specific antimucin peptide antibodies has now allowed measurement of translated mucin gene products ${ }^{5,7}$.

This study focused on airway mucin and its role in the mechanism of respiratory complication of pediatric cardiac surgery. We hypothesized that mucin synthesis and secretion was increased in the airway during cardiopulmonary bypass (CPB) and that this increase would be associated with respiratory complications, such as lung collapse and pneumonia. The relationship between mucin changes and lung injury during CPB was also assessed in the study.

\section{Methods}

\section{Study Population}

Thirty-nine infants and children undergoing cardiac surgery with $\mathrm{CPB}$ at Bristol Children's Hospital were prospectively recruited for the study. The characteristics of the study population are shown in Table 1. Eleven patients who underwent cardiac operations without $\mathrm{CPB}$ during the same period were also recruited for comparison. Excluded were children undergoing emergency cardiac surgery, any patient who had mechanical ventilation before operation, and children with a history of recent respiratory tract infection or other infectious diseases before the operation. No patients with heart disease as a component of a congenital syndrome were included in this study. The study was approved by the local research ethics committee, and informed, written consent was obtained from the parents of all children in the study.

\section{Operations and Ventilator Conditions}

All the operations with $\mathrm{CPB}$ were performed through a median sternotomy, whereas all the operations without CPB were performed through a right or left thoracotomy. Cardiac repairs with CPB were done under total CPB with ascending aortic and bicaval cannulations and cardiac arrest. Anesthesia followed a standard protocol with fentanyl and isoflurane. All patients undergoing CPB received $10 \mathrm{mg} / \mathrm{kg}$ methylprednisolone. 
Ventilator (pressure control) settings were determined by anesthetists to obtain favorable $\mathrm{PaCO}_{2}(35.0-40.0 \mathrm{~mm} \mathrm{Hg})$ and $\mathrm{pH}$ (7.35-7.45) before CPB. Mechanical ventilation was discontinued during $\mathrm{CPB}$, and the lungs were not ventilated until weaning from CPB. To investigate the increase in $\mathrm{PaCO}_{2}$ during $\mathrm{CPB}$, ventilator settings were unchanged (from before $\mathrm{CPB}$ ) until the result of the first blood gas analysis was available after $\mathrm{CPB}$, although inspired oxygen fraction was increased to 1.0 in all cases.

\section{Postoperative Management and Clinical Outcomes}

Intensive care physicians who were not involved in the study managed postoperative treatment, including ventilator settings. Respiratory complications were diagnosed by intensive care physicians and classified by us into four categories according to previously agreed clinical criteria: grade 0 , no respiratory complication; grade 1, significant sputum production, for which physiotherapy including bronchial irrigation was frequently required; grade 2, evidence of lung collapse on chest radiograph in association with sputum production; and grade 3 , pneumonia diagnosed on the basis of clinical, radiologic, and bacteriologic findings.

Blood gas analysis was done before CPB, immediately after $\mathrm{CPB}$, and at 1, 4, and 24 hours after $\mathrm{CPB}$ as long as an arterial line was in situ. Alveolar arterial oxygen difference $\left(\mathrm{PAO}_{2}-\mathrm{PaO}_{2}\right)$ was calculated, except in patients with right-to-left shunts.

\section{Airway Lavage Procedure and Preparation of Samples} Small-volume airway lavage $(1 \mathrm{~mL} / \mathrm{kg}$ body weight $)$ fluid samples were collected by a previously described nonbronchoscopic method. ${ }^{8,9}$ All samples were taken under conditions of general anesthesia, including muscle relaxation. Collection of airway lavage fluid was carried out four times for children undergoing CPB: (1) before the operation, (2) immediately before stopping CPB and restarting mechanical ventilation, (3) 4 hours after $\mathrm{CPB}$ ended, and (4) 24 hours after CPB ended. Airway lavage samples were also collected from children not undergoing CPB before and immediately after the operation. To stabilize mucin in lavage samples, an equal volume of guanidine buffer with inhibitors was added to the airway lavage sample. The samples were stored at $4{ }^{\circ} \mathrm{C}$.

\section{Measurement of Protein and DNA in Airway Lavage Fluid}

Protein concentration in airway lavage fluid was measured with the Bradford dye-binding technique. ${ }^{10}$ DNA concentration was measured with a fluorimetric dye-binding assay as previously described elsewhere. ${ }^{11}$

\section{Analysis of Mucins in Airway Lavage Fluid}

The relative concentrations of the mucins MUC2, MUC5AC, and MUC5B $\mathrm{B}^{5,7,13}$ were determined from slot blots ${ }^{14}$ and calibrated relative to purified major bovine submaxillary gland mucin ${ }^{12}$ as a reference standard. The amount of glycoprotein (largely mucin) was detected in the lavage samples with wheat germ agglutininhorseradish peroxidase conjugate (Vector Labs, Peterborough, UK) and calibrated with major bovine submaxillary gland mucin before measurement with specific antimucin antisera. All unknown samples were measured on the same blot membrane as the major bovine submaxillary gland mucin standards to eliminate reagent and membrane artifacts. According to the value of glycoprotein determined with wheat germ agglutinin, equivalent amounts of the lavage samples were applied to polyvinylidine fluoride membranes (Millipore, Watford, UK) and tested for reactivity with each of the antimucin antibodies. The monoclonal antibody NCL-HGM-45M1 (Novocastra Laboratories Ltd, Newcastle upon Tyne, UK) was used for MUC5AC at 1:1600; polyclonal antibody M5B was used for $\operatorname{MUC5B}^{7}$ (1:2000), and polyclonal antibody LUM2-3 was used for MUC2 $2^{13}$ (1:2000). Detection was as described before, and the blots were scanned with a Hewlett-Packard HP2C scanner (Hewlett-Packard Ltd, Bracknell, UK). Their intensity was measured densitometrically with Optimas Bioscan Software (Bioscan, Inc, Washington, DC).

Calibration curves were determined with standard preparations containing MUC5AC and MUC5B, isolated from human respiratory tract lavage samples purified by density-gradient centrifugation, ${ }^{7,13,14}$ and a MUC2 standard generated by glutaraldehyde cross-linking of the LUM2-3 immunizing peptide NGLQPVRVEDPDGC (MWG Biotech), with bovine serum albumin and purification by Sephadex G25 chromatography (Amersham Pharmacia Biotech AB, Uppsala, Sweden). ${ }^{15}$. The optical densities of slot blots for unknown lavage samples with each antimucin antibody were measured within the linear range of the calibration curve for the standards. The mucin content of each lavage sample was calculated as micrograms of mucin (MUC5AC/ MUC5B) and micrograms of MUC2 peptide-bovine serum albumin equivalent. The sum of MUC5AC, MUC5B, and MUC2 values was calculated as total mucins, and the ratio MUC5AC to total mucins was the MUC5AC ratio.

\section{Data Expression and Statistical Analyses}

Mucin and glycoprotein concentrations in airway lavage fluid were calculated as micrograms per microgram of protein, and DNA concentrations were calculated as nanograms per microgram of protein. Data in the text and table are expressed as median and interquartile range. Changes in mucin and DNA concentrations after CPB were calculated by subtraction of the pre-CPB value from the immediate post-CPB value.

All statistical analyses were performed with SPSS 11.0J for Windows (SPSS Inc, Chicago, Ill). Because most of the data were not normally distributed, nonparametric tests were used for all analyses. Differences between two groups were evaluated with the Mann-Whitney $U$ test. When three or more groups were compared, the Kruskal-Wallis test was applied before Mann-Whitney $U$ test, and if the $P$ value thus obtained was less than .05 , the Bonferroni correction was applied. To investigate the differences between preoperative values and measurements at different time points within each group, the Friedman test was performed initially; and if the $P$ value was less than .05 , the Wilcoxon test and the Bonferroni correction were applied to identify the significant differences. The Spearman test was used to investigate the correlation between any mucin values and preoperative and intraoperative factors or grades of lung injury.

\section{Results}

All 50 patients had satisfactory cardiac function on postoperative echocardiographic analysis. Airway lavage fluid samples were available for all children before and after CPB or operation, but the number of samples decreased to 33 (22 

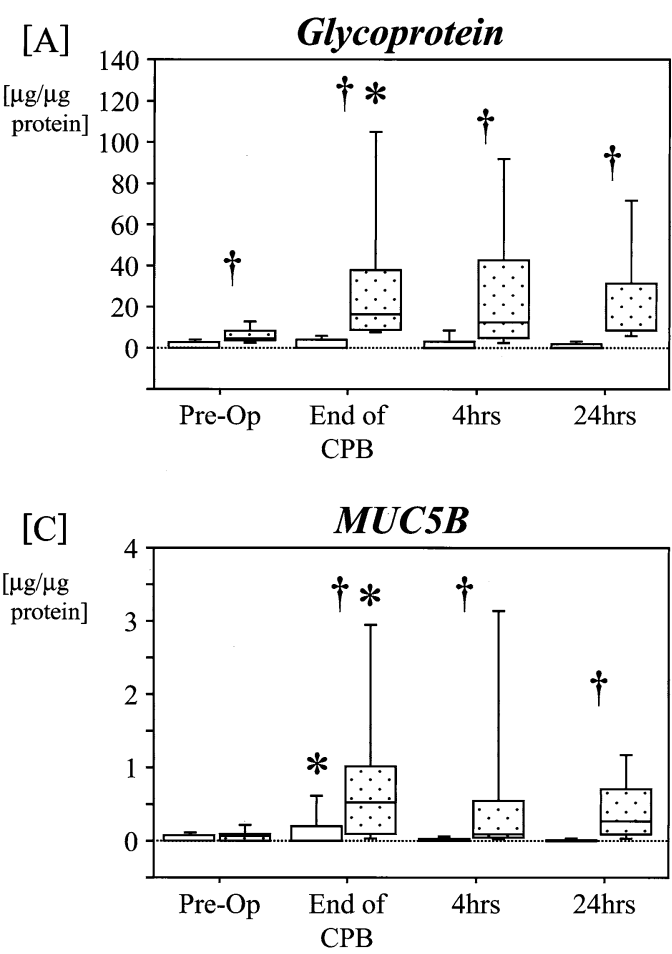
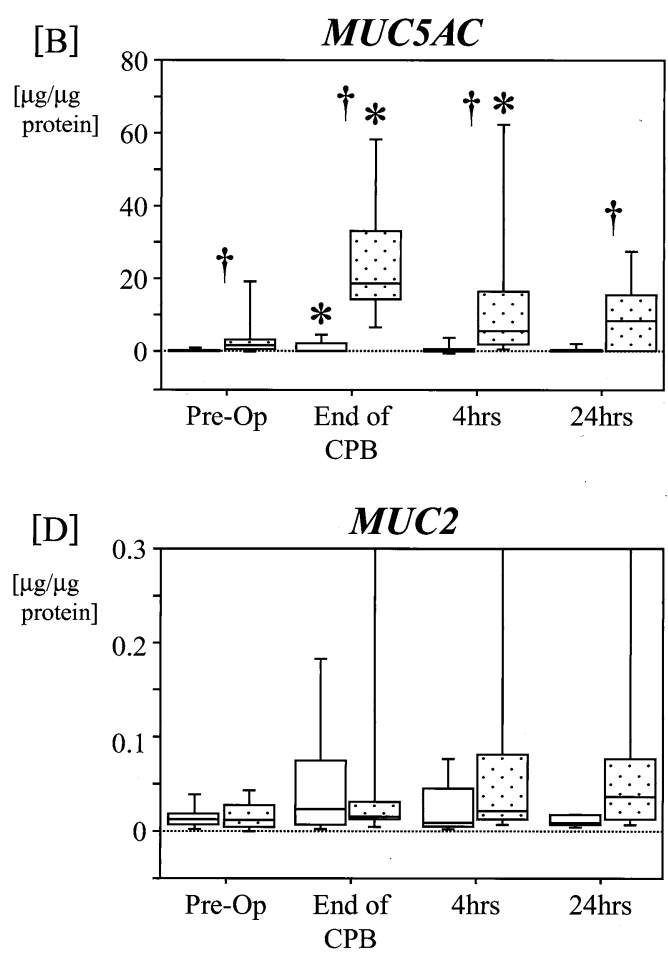

Figure 1. Time-dependent changes in glycoprotein (A), MUC5AC (B), MUC5B (C), and MUC2 (D) in patients with (dotted boxes) and without (open boxes) respiratory complications before (Pre-Op) and after CPB. Boxes represent interquartile range (25-75 percentile); line within each box represents median. Bars show 10th and 90th percentiles. Dagger indicates $\boldsymbol{P}<.05$ versus group without respiratory complications; asterisk indicates $\boldsymbol{P}<.05$ versus preoperative value.

without and 11 with respiratory complications) and 15 (7 without and 8 with respiratory complications) at 4 and 24 hours after CPB, respectively, because of the cessation of assisted ventilation. Respiratory complications of grades 1 , 2 , and 3 were detected in 3, 7, and 4 patients, respectively.

\section{Mucin and Glycoprotein Changes During and After CPB}

Protein concentrations in sequential lavage samples were relatively constant (before CPB $0.34 \mu \mathrm{g} / \mu \mathrm{L}$, interquartile range $0.18-0.79 \mu \mathrm{g} / \mu \mathrm{L}$, after CPB $0.35 \mu \mathrm{g} / \mu \mathrm{L}$, interquartile range $0.21-0.67 \mu \mathrm{g} / \mu \mathrm{L}, 4$ hours $0.40 \mu \mathrm{g} / \mu \mathrm{L}$, interquartile range $0.20-0.67 \mu \mathrm{g} / \mu \mathrm{L}, 24$ hours $0.29 \mu \mathrm{g} / \mu \mathrm{L}$, interquartile range $0.17-0.79 \mu \mathrm{g} / \mu \mathrm{L}$ ). Glycoprotein showed significant increase during $\mathrm{CPB}$ in the respiratory complication group. There were significant increases in MUC5AC and MUC5B concentrations but not in MUC2 after CPB in patients both with and without respiratory complications (Figure 1). At all time points before and after the operation, glycoprotein and MUC5AC measurements were significantly higher in patients with respiratory complications than in those without (glycoprotein: pre $P<.0001$, post $P<.0001,4$ h $P=$ $.0004,24 \mathrm{~h} P=.0012$; MUC5AC: pre $P=.0002$, post $P<$ $.0001,4$ h $P<.0001,24$ h $P=.021$; Figure $1, A$ and $B$ ).
MUC5B concentration was also higher in patients with respiratory complications after $\mathrm{CPB}(P=.012$ immediately after CPB, $P=.0002$ at 4 hours, and $P=.003$ at 24 hours after CPB (Figure 1, C).

None of the following preoperative or intraoperative factors were significantly associated with airway lavage fluid mucin concentration: age, body weight, aortic crossclamp and CPB times, circulatory arrest duration, lowest rectal temperature, and hemoglobin concentration during CPB $(r<0.2$ and $P>$.2). Only CPB duration had a weakly positive correlation with MUC5AC concentration immediately after CPB $(r=0.31, P=.05)$. There were no significant differences between children with and without respiratory complications in these variables.

Patients with respiratory complications also had a greater proportion of MUC5AC before and up to 4 hours after operation than did patients without respiratory complications (before $P=.008$, after $P=.0002,4 \mathrm{~h} P=.01$; Figure 2).

\section{Mucin Increase and Grade of Respiratory Complications}

Although there were relatively few subjects in each category of respiratory complication, patients with grade 2 and 


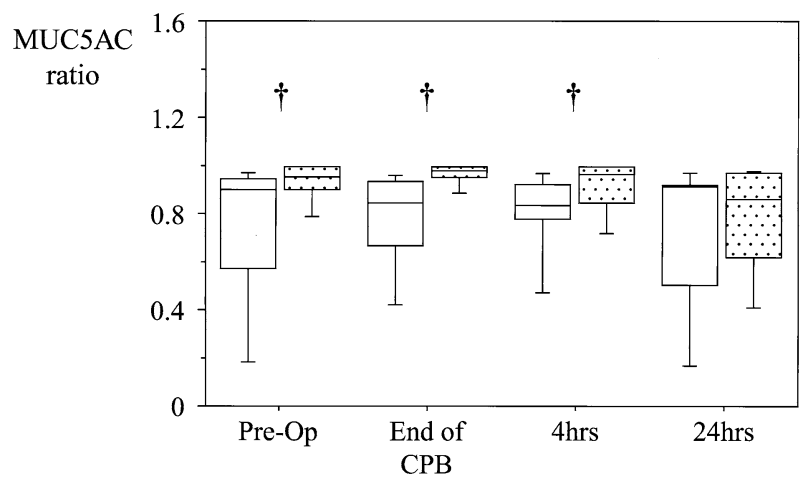

Figure 2. Time-dependent change in ratio of MUC5AC to total mucins in patients with (dotted boxes) and without (open boxes) respiratory complications before (Pre-Op) and after CPB. Boxes represent interquartile range (25th to 75 th percentile); line within each box represents median. Bars show 10th and 90th percentiles. Dagger indicates $\boldsymbol{P}<.05$ versus group without respiratory complications.

3 respiratory complications showed a significantly greater increase in total mucin during CPB than did patients with grade 0 (grade 2, $P=.002$; grade $3, P=.01$ ). Furthermore, the increase of total mucin in grade 3 tended to be higher than that in grade $1(P=.10)$. There was a significant correlation between the increase of total mucin during CPB and the grade of respiratory complication $(r=0.70, P<$ .01 ; Figure 3 ). Total mucin at 4 hours after CPB still showed significant correlation with the grade of respiratory complications (data not shown).

\section{Relationship Between Mucin Increase and Lung Injury}

Airway lavage fluid DNA content significantly increased during CPB (4.3 $\mathrm{ng} / \mu \mathrm{g}$ protein, interquartile range 1.9-7.3 $\mathrm{ng} / \mu \mathrm{g}$ protein, to $18.1 \mathrm{ng} / \mu \mathrm{g}$ protein, interquartile range $6.3-38.4 \mathrm{ng} / \mu \mathrm{g}$ protein, $P<.0001$ ), and the increase of DNA during CPB showed a positive correlation with the duration of CPB $(P=.004)$ and increase of total mucin during CPB $(P<.0001$, Figure $4, A) . \mathrm{PAO}_{2}-\mathrm{PaO}_{2}$ increased after $\mathrm{CPB}(240.2 \mathrm{~mm} \mathrm{Hg}$, interquartile range 126.1-282.2 $\mathrm{mm} \mathrm{Hg}$, to $402.4 \mathrm{~mm} \mathrm{Hg}$, interquartile range $370.0-510.7 \mathrm{~mm} \mathrm{Hg}, P<.0001$ ), and there was a positive correlation between $\mathrm{PAO}_{2}-\mathrm{PaO}_{2}$ immediately after $\mathrm{CPB}$ and the increase of total mucin during $\mathrm{CPB}(P=.0007$; Figure 4, $B) . \mathrm{PaCO}_{2}$ also increased after CPB $(32.0 \mathrm{~mm}$ $\mathrm{Hg}$, interquartile range $28.6-36.4 \mathrm{~mm} \mathrm{Hg}$, to $37.8 \mathrm{~mm} \mathrm{Hg}$, interquartile range $32.9-42.1 \mathrm{~mm} \mathrm{Hg}, P<.0001$ ), and there was a positive correlation between $\mathrm{PaCO}_{2}$ immediately after $\mathrm{CPB}$ and an increase of total mucin during CPB $(P<.0001$; Figure 4, $C)$.

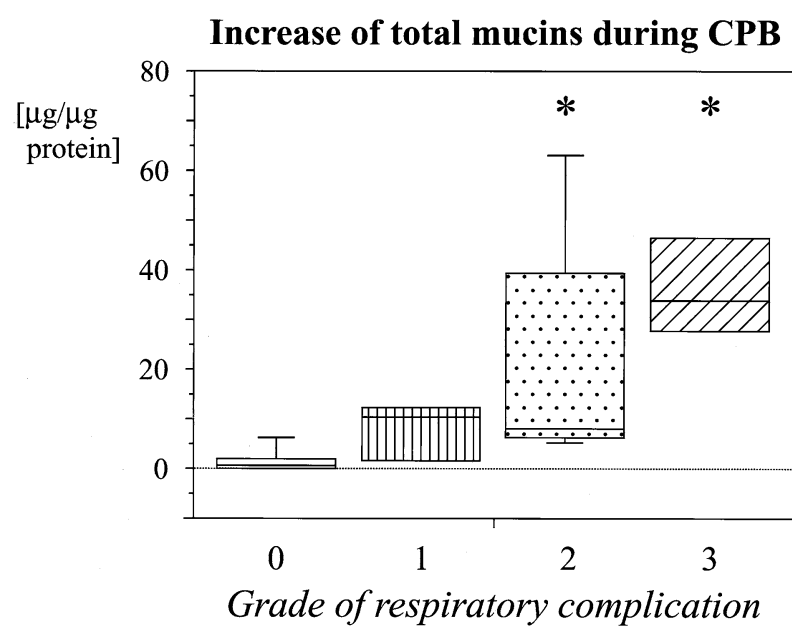

Figure 3. Relationship between grade of respiratory complication (see text for definitions) and increase in total mucin during CPB (grade 0, $n=25$; grade 1, $n=3$; grade 2, $n=7$; grade 3, $n=4$ ). Boxes represent interquartile range (25th to 75 th percentile); line within each box represents median. Bars show 10th and 90th percentiles. Asterisk indicates $\boldsymbol{P}<.01$ versus grade 0 .

\section{Mucin Changes During Operations Without CPB}

There were no significant changes in glycoprotein concentration $(0.50 \mu \mathrm{g} / \mu \mathrm{g}$ protein, interquartile range $0.34-0.82$ $\mu \mathrm{g} / \mu \mathrm{g}$ protein, to $0.70 \mu \mathrm{g} / \mu \mathrm{g}$ protein, interquartile range $\mu \mathrm{g} / \mu \mathrm{g}$ protein, interquartile range $0.54-0.81 \mu \mathrm{g} / \mu \mathrm{g}$ protein), any mucin components (MUC5AC $0.31 \mu \mathrm{g} / \mu \mathrm{g}$ protein, interquartile range $0.08-0.56 \mu \mathrm{g} / \mu \mathrm{g}$ protein, to $0.25 \mu \mathrm{g} / \mu \mathrm{g}$ protein, interquartile range $0.10-0.53 \mu \mathrm{g} / \mu \mathrm{g}$ protein; MUC5B $0.04 \mu \mathrm{g} / \mu \mathrm{g}$ protein, interquartile range 0.02-0.09 $\mu \mathrm{g} / \mu \mathrm{g}$ protein, to $0.05 \mu \mathrm{g} / \mu \mathrm{g}$ protein, interquartile range $0.02-0.10 \mu \mathrm{g} / \mu \mathrm{g}$ protein; MUC2 $0.01 \mu \mathrm{g} / \mu \mathrm{g}$ protein, interquartile range $0.004-0.022 \mu \mathrm{g} / \mu \mathrm{g}$ protein, to $0.04 \mu \mathrm{g} / \mu \mathrm{g}$ protein, interquartile range $0.008-0.061 \mu \mathrm{g} / \mu \mathrm{g}$ protein), and DNA level $(4.1 \mathrm{ng} / \mu \mathrm{g}$ protein, interquartile range 2.7-7.3 $\mathrm{ng} / \mu \mathrm{g}$ protein, to $5.0 \mathrm{ng} / \mu \mathrm{g}$ protein, interquartile range 2.1-10.1 $\mathrm{ng} / \mu \mathrm{g}$ protein) in airway lavage fluid during operation without CPB. Three children had atelectasis of the lungs on the side of thoracotomy after operation. Although MUC5AC and MUC5B levels were slightly higher in patients with respiratory complications after operation (MUC5AC $0.30 \mu \mathrm{g} / \mu \mathrm{g}$ protein, interquartile range 0.09$0.39 \mu \mathrm{g} / \mu \mathrm{g}$ protein, vs $1.66 \mu \mathrm{g} / \mu \mathrm{g}$ protein, interquartile range $0.50-2.16 \mu \mathrm{g} / \mu \mathrm{g}$ protein; MUC5B $0.05 \mu \mathrm{g} / \mu \mathrm{g}$ protein, interquartile range $0.03-0.07 \mu \mathrm{g} / \mu \mathrm{g}$ protein, vs 0.10 $\mu \mathrm{g} / \mu \mathrm{g}$ protein, interquartile range $0.09-0.19 \mu \mathrm{g} / \mu \mathrm{g}$ protein), the numbers of subjects were too small to allow meaningful statistical comparisons.

\section{Discussion}

To our knowledge, this is the first study to demonstrate that increases in respiratory mucins in airway lavage fluid are 

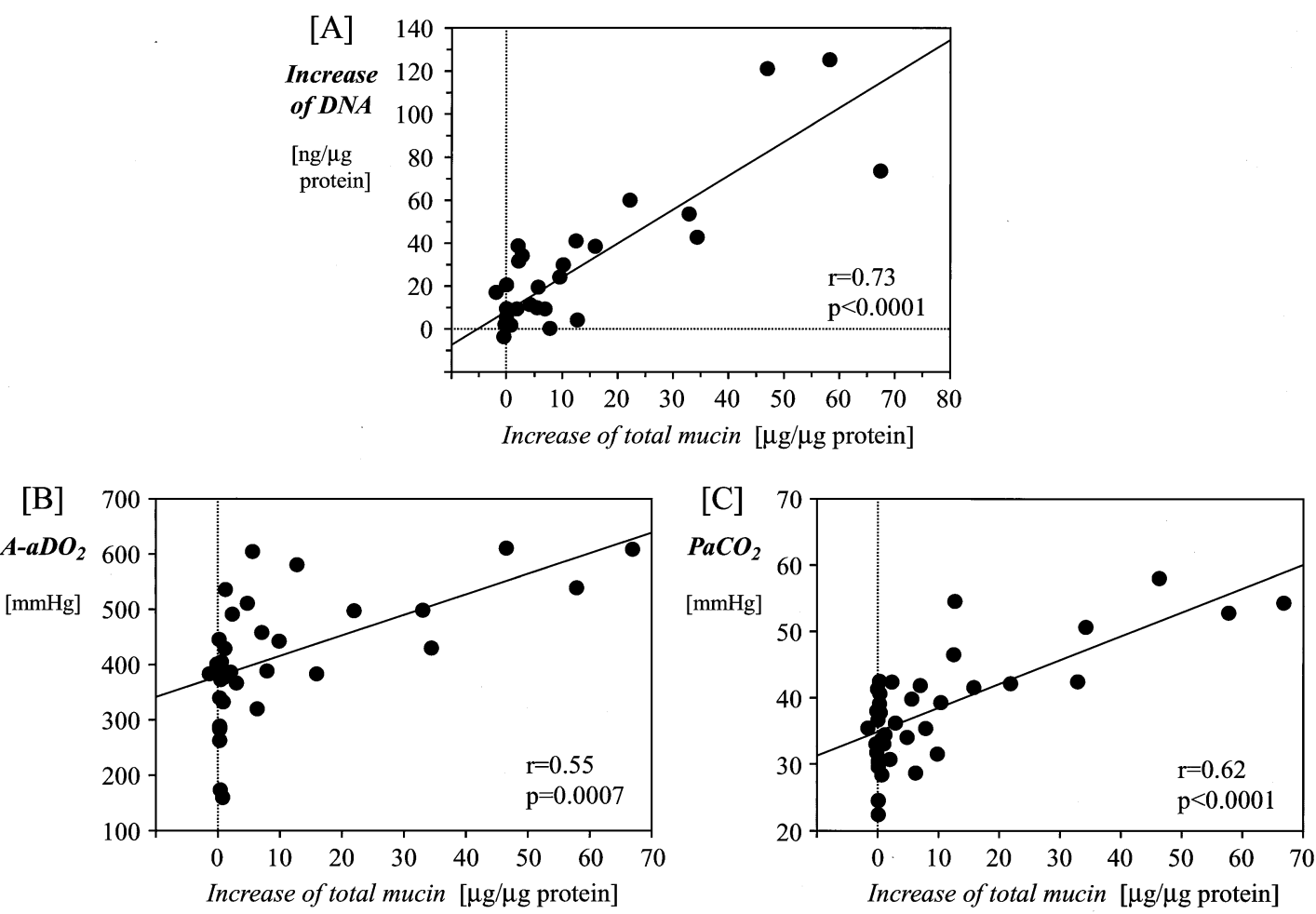

Figure 4. Relationship between increase in total mucin and physiologic indicators of lung injury: DNA in airway lavage fluid (A), alveolar arterial oxygen difference $\left(\mathrm{A}-\mathrm{aO}_{2} ; \mathrm{B}\right)$, and $\mathrm{PaCO}_{2}(\mathrm{C})$.

associated with respiratory complications after CPB. Respiratory complications are common sequelae of cardiac surgery in infants and young children. We observed respiratory complications in $34 \%$ of our patients in this study, including pneumonia in $10.4 \%$, and these incidences were similar to those in previous reports. Previous studies have demonstrated that increased mucin concentration is associated with airway obstruction, gas exchange abnormalities, and bacterial infections of the lungs ${ }^{15,16}$. These observations are consistent with our results, which demonstrate an association between increased mucin concentration and increased $\mathrm{PAO}_{2}-\mathrm{PaO}_{2}$ gradient.

There are several possible explanations for our observations. An increase in mucin could result from increased synthesis, increased secretion of stored mucin, decreased mucin clearance, or cell destruction with release of cell contents into the airway lumen. The relationship between increases of mucins and DNA during CPB in our results may reflect cell injury with passive leakage of stored mucin from damaged epithelial cells. However, active secretion in response to pulmonary inflammation associated with CPB appears to be the most likely explanation, although specific mechanisms were not identified in this study.

Support for a direct relationship between the degree of acute lung injury and increased mucin production or secretion has been reported. ${ }^{17} \mathrm{CPB}$ is known to cause an acute inflammatory response in the lungs, with marked increases in several proinflammatory cytokines and in neutrophil elastase,${ }^{18}$ and these may be responsible for direct cytokine- or neutrophil elastase-mediated stimulation of mucin production. ${ }^{19,20}$ In vitro studies have shown increased production of mucin in association with interleukin $9^{19}$ and interleukin 13 , and neutrophil elastase is associated with damage to cilia, reduction in ciliary function, ${ }^{20}$ increased mucin production, ${ }^{21}$ and upregulation of mucin gene expression. ${ }^{22}$

The greater proportion of MUC5AC that was observed in patients with respiratory complications implicates a mucosal surface event in these subjects, because MUC5AC is located in the superficial epithelium and MUC5B is located in the submucosal glands. ${ }^{5,13}$ This specific change in mucin composition suggests that our observations are not simply the result of a generalized pulmonary insult, with passive release of mucin from disrupted epithelial cells. The relationships between risk factors for lung injury, including CPB time and increased DNA and total mucin contents, suggest that the increased airway mucin concentrations are related to an inflammatory lung injury.

One potentially important finding of our study is the observation that patients who had postoperative respiratory complications had a higher proportion of MUC5AC in the preoperative airway lavage sample. This may imply that these children had subclinical infections before the opera- 
tion and were therefore predisposed toward respiratory complications. Alternatively, if these children had high constitutive expression of MUC5AC that predisposed them toward respiratory complications, this measurement may have a place as a predictive factor for pulmonary complications of cardiac surgery in children and deserves further evaluation.

The findings in subjects who had operations without CPB implicate CPB as the major factor in determining postoperative mucin responses, rather than the operative procedure itself. Three children had respiratory complications without significant increase of mucin after operation without CPB. This may be explained by the difference in mechanisms of respiratory complications between operations with and without CPB or median sternotomy and thoracotomy. Our observation that all the respiratory complications in children without CPB were atelectasis seen on the same side as the thoracotomy may indicate the direct influence of surgical procedure on the lungs. Further investigations are necessary to elucidate the details of these mechanisms.

We thank Ms C. Gillen for her expertise in obtaining samples. We are grateful to the following for the gifts of antimucin antibodies: Professor I. Carlstedt, Department of Cell and Molecular Biology, University of Lund, Sweden, for LUM2-3, and Drs D. Thornton and J. Sheehan, Wellcome Trust Centre for Matrix Research, University of Manchester, United Kingdom, for M5B.

\section{References}

1. Chang AC. Pediatric cardiac intensive care: current state of the art and beyond the millennium. Curr Opin Pediatr. 2000;12:238-46.

2. Dicarlo JV, Raphaely RC, Steven JM, Norwood WI, Costarino AT. Pulmonary mechanics in infants after cardiac surgery. Crit Care Med. 1992;20:22-7.

3. Fischer JE, Allen P, Fanconi S. Delay of extubation in neonates and children after cardiac surgery: impact of ventilator-associated pneumonia. Intensive Care Med. 2000;26:942-9.

4. Krastins IR, Corey ML, McLeod A, Edmonds J, Levison H, Moes F. An evaluation of incentive spirometry in the management of pulmonary complications after cardiac surgery in a pediatric population. Crit Care Med. 1982;10:525-8.

5. Hovenberg HW, Davies JR, Carlstedt I. Different mucins are produced by the surface epithelium and the submucosa in human trachea: identification of MUC5AC as a major mucin from the goblet cells. Biochem J. 1996;318:319-24.

6. Roussel P. Airway glycoconjugates and cystic fibrosis. Glycoconj J. 2001;18:645-7.

7. Thornton DJ, Howard M, Khan N, Sheehan JK. Identification of two glycoforms of the MUC5B mucin in human respiratory mucusevidence for a cysteine-rich sequence repeated within the molecule. J Biol Chem. 1997;272:9561-6.

8. Griese M, Wilnhammer C, Jansen S, Rinker C. Cardiopulmonary bypass reduces pulmonary surfactant activity in infants. $J$ Thorac Cardiovasc Surg. 1999;118:237-44.

9. Grigg J, Arnon S, Silverman M. Fractional processing of sequential bronchoalveolar lavage fluid from intubated babies. Eur Respir J. 1992;5:727-32.

10. Bradford M. A rapid and sensitive method for the quantitation of microgram quantities of protein utilising the principle of protein-dye binding. Anal Biochem. 1976;72:248-54.

11. Probert CS, Warren BF, Perry T, Mackay EH, Mayberry JF, Corfield AP. South Asian and European colitics show characteristic differences in colonic mucus glycoprotein type and turnover. Gut. 1995;36:696702.

12. Corfield AP, Corfield CD, Veh RW, Wagner SA, Clamp JR, Schauer R. Characterization of the major and minor mucus glycoproteins from bovine submandibular gland. Glycoconj J. 1991;8:330-9.

13. Hovenberg HW, Davies JR, Herrmann A, Linden CJ, Carlstedt I. MUC5AC, but not MUC2, is a prominent mucin in respiratory secretions. Glycoconj J. 1996;13:839-47.

14. McGuckin MA, Thornton DJ. Detection and quantitation of mucins using chemical, lectin and antibody methods. In: Corfield AP, editor. Glycoprotein methods and protocols: the mucins. Totowa (NJ): Humana Press; 2000. p. 45-55.

15. Aikawa T, Shimura S, Sasaki H, Ebina M, Takishima T. Marked goblet cell hyperplasia with mucus accumulation in the airways of patients who died of severe acute asthma attack. Chest. 1992;101:91621.

16. Bernstein JM, Reddy M. Bacteria-mucin interaction in the upper aerodigestive tract shows striking heterogeneity: implications in otitis media, rhinosinusitis, and pneumonia. Otolaryngol Head Neck Surg. 2000;122:514-20.

17. Shih JY, Yang SC, Yu CJ, Wu HD, Liaw YS, Wu R, et al. Elevated serum levels of mucin-associated antigen in patients with acute respiratory distress syndrome. Am J Respir Crit Care Med. 1997;156: 1453-7.

18. Kotani N, Hashimoto H, Sessler DI, Muraoka M, Wang JS, O'Connor MF, et al. Neutrophil number and interleukin- 8 and elastase concentrations in bronchoalveolar lavage fluid correlate with decreased arterial oxygenation after cardiopulmonary bypass. Anesth Analg. 2000; 90:1046-51.

19. Louahed J, Toda M, Jen J, Hamid Q, Renauld JC, Levitt RC, et al. Interleukin-9 upregulates mucus expression in the airways. Am $J$ Respir Cell Mol Biol. 2000;22:649-56.

20. Amitani R, Wilson R, Rutman A, Read R, Ward C, Burnett D, et al. Effects of human neutrophil elastase and Pseudomonas aeruginosa proteinases on human respiratory epithelium. Am J Respir Cell Mol Biol. 1991;4:26-32.

21. Breuer R, Christensen TG, Lucey EC, Stone PJ, Snider GL. An ultrastructural morphometric analysis of elastase-treated hamster bronchi shows discharge followed by progressive accumulation of secretory granules. Am Rev Respir Dis. 1987;136:698-703.

22. Voynow JA, Young LR, Wang Y, et al. Neutrophil elastase increases MUC5AC mRNA and protein expression in respiratory epithelial cells. Am J Physiol. 1999;276:L835-43. 